\title{
Anaplastic lymphoma kinase fusions: Roles in cancer and therapeutic perspectives (Review)
}

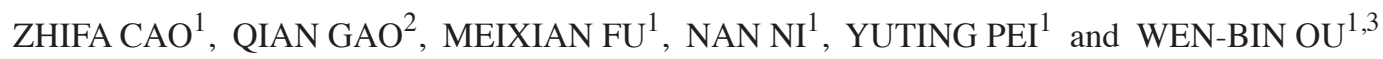 \\ ${ }^{1}$ Zhejiang Provincial Key Laboratory of Silkworm Bioreactors and Biomedicine, College of Life Sciences, \\ Zhejiang Sci-Tech University, Hangzhou, Zhejiang 310018; ${ }^{2}$ Emergency Department, Tianjin Fourth Central Hospital, \\ Fourth Central Hospital Affiliated with Nankai University, Tianjin 300140; ${ }^{3}$ Zhejiang Provincial Key Laboratory of \\ Applied Enzymology, Yangtze Delta Region Institute of Tsinghua University, Jiaxing, Zhejiang 314006, P.R. China
}

Received April 23, 2018; Accepted November 27, 2018

DOI: $10.3892 / 01.2018 .9856$

\begin{abstract}
Receptor tyrosine kinase (RTK) anaplastic lymphoma kinase (ALK) serves a crucial role in brain development. $A L K$ is located on the short arm of chromosome 2 (2p23) and exchange of chromosomal segments with other genes, including nucleophosmin $(N P M)$, echinoderm microtubule-associated protein-like 4 (EML4) and Trk-fused gene (TFG), readily occurs. Such chromosomal translocation results in the formation of chimeric $X$-ALK fusion oncoproteins, which possess potential oncogenic functions due to constitutive activation of ALK kinase. These proteins contribute to the pathogenesis of various hematological malignancies and solid tumors, including lymphoma, lung cancer, inflammatory myofibroblastic tumors (IMTs), Spitz tumors, renal carcinoma, thyroid cancer, digestive tract cancer, breast cancer, leukemia and ovarian carcinoma. Targeting of ALK fusion oncoproteins exclusively, or in combination with ALK kinase inhibitors including crizotinib, is the most common therapeutic strategy. As is often the case for small-molecule tyrosine kinase inhibitors (TKIs), drug resistance eventually develops via an adaptive secondary mutation in the $A L K$ fusion oncogene, or through engagement of alternative signaling mechanisms. The updated mechanisms of a variety of $A L K$ fusions in tumorigenesis, proliferation and metastasis, in addition to targeted therapies are discussed below.
\end{abstract}

\section{Contents}

1. Introduction

2. ALK rearrangement

Correspondence to: Dr Wen-Bin Ou, Zhejiang Provincial Key Laboratory of Silkworm Bioreactors and Biomedicine, College of Life Sciences, Zhejiang Sci-Tech University, 928 Second Avenue, Xiasha Higher Education Zone, Hangzhou, Zhejiang 310018, P.R. China E-mail: ouwenbin@tsinghua.org.cn

Key words: anaplastic lymphoma kinase, fusion variants, oncogene, targeted therapy, resistance mechanisms
3. Roles of ALK fusion oncoproteins in cancer pathogenesis

4. Therapeutic implications

5. Conclusion

\section{Introduction}

Located on chromosome 2 p23, receptor tyrosine kinase (RTK) anaplastic lymphoma kinase (ALK) is physiologically expressed in fetal neural cells. Phosphorylated and activated ALK controls the basic mechanisms of cell proliferation, survival and differentiation during development of the nervous system (1). In 1994 ALK t(2;5) chromosomal translocation was reported in anaplastic large cell lymphoma (ALCL) (2). This translocation induced formation of the nucleophosmin (NPM)-ALK chimeric protein (3). Over the ensuing two decades, $A L K$ fusion oncogenes have been associated with the development of diverse tumor types of different lineages, including, but not limited to, lymphoma, lung cancer, inflammatory myofibroblastic tumors (IMTs), Spitz tumors, renal carcinoma, thyroid cancer, digestive tract cancer, breast cancer, leukemia and ovarian carcinoma. During this period, the discovery of $E M L 4-A L K$ in non-small cell lung cancer (NSCLC) was a major development that led to significant diagnostic and therapeutic advances (4).

In general, $A L K$ fusions arise from fusion of the $3^{\prime}$ end of the $A L K$ gene (exons 20-29) with the 5'portion of a different gene (5). To date, numerous X-ALK fusion oncoproteins have been identified in various tumor types of different lineages. Although targeting $A L K$ fusions markedly promotes tumor shrinkage due to acquisition of activating mutations, genomic rearrangement or copy number amplification of $A L K$, a subset of patients inevitably acquire resistance to ALK inhibitors. The functional roles of a variety of $A L K$ fusions in neoplasms and targeted therapy advances are summarized below.

\section{2. $A L K$ rearrangement}

In the majority of cancer types, $A L K$ is activated via chromosomal rearrangement. The breakpoint of $A L K$ often occurs at intron 19 , which results in dissociation of the $3^{\prime}$ end of exons 20-29 from 5' end sequences, including the gene 
promoter, regulatory elements and coding sequences corresponding to the extracellular and transmembrane domains of $A L K$. The other breakpoint affects a diverse group of genes that contribute to the fusion oncogene, including a different gene promoter and a series of 5' exons of variable lengths and properties, which predominantly share the ability to self-associate. Additionally, clinical data indicate that different fusion partners affect treatment responses in patients with lung cancer (6). The resulting fusion oncoproteins (X-ALK) are chimeric, self-associating polypeptides with a variety of N-terminal domains and a common, constitutively active C-terminal tyrosine kinase domain (Fig. 1) (5).

In 1994, Morris et al (2), first demonstrated NPM-ALK expression in ALCL. Subsequently, a variety of fusion partners have been found (Table I), including the following: $\alpha$-2-macroglobulin (A2M); 5-aminoimidazole-4-carboxamide ribonucleotide formyltransferase (ATIC); carbamoyl-phosphate synthetase 2, aspartate transcarbamylase, and dihydroorotase $(C A D)$; cysteinyl-tRNA synthetase $(C A R S)$; clathrin heavy chain (CLTC); dynactin (DCTN1); echinoderm microtubule-associated protein like-4 (EML4); fibronectin 1 (FN1); huntingtin-interacting protein 1 (HIPl); kinesin family member 5B (KIF5B); kinesin light chain 1 (KLC1); moesin $(M S N)$; non-muscle myosin heavy chain 9 (MYH9); PTPRF interacting protein, binding protein 1 (PPFIBP1); RAN binding protein $2(R A N B P 2)$; ring finger protein 213 (RNF213); SEC31 homolog A (SEC31A); spectrin beta non-erythrocytic 1 (SPTBN1); sequestosome 1 (SQSTM1); striatin (STRN); TRK-fused gene $(T F G)$; tropomyosin 3 (TPM3); tropomyosin 4 (TPM4); translocated promoter region (TPR); TNF receptor-associated factor 1 (TRAFI); and vinculin (VCL).

The precise mechanisms of $A L K$ gene rearrangement remain unclear. Widely considered a key source of genomic rearrangement, non-homologous end-joining may be divided into 3 steps: i) Generation of double-stranded DNA breaks; ii) ligation of DNA; and iii) gene rearrangement $(7,8)$. Fluorescence in situ hybridization (FISH) and immunohistochemistry (IHC) are widely used in clinical settings to detect $A L K$ rearrangements (9-11). However, FISH and IHC exhibit low specificity in the recognition of fusion partners, which may be identified by reverse transcription polymerase chain reaction (RT-PCR) or rapid amplification of cDNA ends (RACE)-coupled PCR sequencing $(10,12)$.

\section{Roles of ALK fusion oncoproteins in cancer pathogenesis}

Lymphoma. Lymphomas comprise a group of blood cancer types that develop from lymphocytes and are classified as either Hodgkin's lymphoma (HL, 10\%) or non-Hodgkin's (NHL, 90\%) lymphoma. Based on the normal function of lymphocytes, NHL may be further divided into three subtypes: i) B cell NHL; ii) T cell NHL; and iii) natural killer cell NHL. Compared with HL, NHL patients have a poor prognosis, and the five-year survival rate is $\sim 69 \%(13,14)$.

According to certain studies, $A L K$ rearrangements are commonin ALCL, whichisatypeofT cell NHL(15).Statistically, a total of $~ 90 \%$ of ALCLs in children and teenagers, and $50 \%$ of ALCLs in adults are ALK-fusion-positive (16-18). The most frequent $A L K$ fusion partner is $N P M$, as the ALK-NPM fusion protein is observed in $\sim 70-80 \%$ of all ALCL cases. A total of $\sim 25 \%$ cases of ALCL exhibit the TPM3-ALK rearrangement, whereas other rearrangements, including $T F G-A L K$, $A T I C-A L K$ and $C L T C 1-A L K$, are rare (Table I). Notably, the prognoses of patients with ALK-fusion-positive ALCL are substantially improved compared with those of patients with ALK-fusion-negative ALCL (the five-year survival rate is $70-80 \%$ for ALK-fusion-positive patients compared with $15-45 \%$ for ALK-fusion-negative patients) $(19,20)$.

Expression of X-ALK was thought to be restricted to ALK-fusion-positive ALCLs; however, in 1997, Delsol et al (21), first demonstrated aberrant expression of NPM-ALK in diffuse large B cell lymphoma (DLBCL). ALK-fusion-positive DLBCL is usually a nodal disease that affects 34 55 years old males, presents at advanced clinical stages and has a poor prognosis (22). The most common $A L K$ rearrangement in DLBCL is $\mathrm{t}(2 ; 17)(\mathrm{p} 23 ; \mathrm{q} 23)$, which corresponds to the $C L T C$ - $A L K$ fusion; a minority are NPM-ALK rearrangements (23). Rare cases that harbor SEC31A-ALK and SQSTM1-ALK fusions have also been described (24-27).

Lung cancer. Lung cancer is the most prevalent type of cancer and the leading cause of mortality among all malignancies. Despite tremendous progress in the diagnosis and treatment of lung cancer, prognosis for these patients remains poor, with only $15 \%$ surviving more than 5 years after initial diagnosis (28). NSCLC accounts for $\sim 80-85 \%$ of these cases of lung cancer, whereas the remainder involve small cell lung cancer and lung carcinoid tumors (29).

The EML4-ALK fusion was first observed in 5 out of 75 (6.7\%) Japanese patients with NSCLC; notably, these patients did not harbor epidermal growth factor receptor $(E G F R)$ or $K R A S$ mutations (4). Multiple studies have determined the frequency of the EML4-ALK translocation in NSCLC patients, which ranges from 2 to $7 \%$ in individual studies, with an average frequency of $\sim 5 \%$ (30-37). During the past decade, over 11 different variants of $E M L 4-A L K$ have been identified in a variety of tumors, including NSCLC, digestive tract and breast cancer. The most common variant among EML4-ALK fusions is variant $1(33 \%)$, followed by variant $3(29 \%)$ and variant $2(10 \%)(12,38)$. Furthermore, other $A L K$ fusion partners have been identified in NSCLC, including $K L C, T F G, K L C$, and $K I F 5 B$ (39-41). $A L K$-rearranged NSCLC is frequently observed in young patients, in addition to never or former light smokers. Morphologically, acinar, tubulopapillary, cribriform and solid patterns are the most common histological subtypes, and $>10 \%$ of tumor cells display a distinctive signet ring morphology with abundant intracellular mucin (42). In addition, the oncogenic potential of $X$ - $A L K$ has been confirmed in lung cancer models, including patient-derived cell lines and transgenic mouse models. Several studies have identified the $X$-ALK gene in a number of NSCLC patients harboring EGFR mutations (38,43-46). The majority of these patients are insensitive to the ALK inhibitor crizotinib, but exhibit a partial response to the EGFR inhibitor erlotinib. Therefore, they may not further benefit from coordinated treatment with ALK and EGFR inhibitors compared with either intervention alone.

IMTs. IMT is a type of mesenchymal neoplasm composed of a mixture of several inflammatory cells, which primarily occurs in children $(47,48)$. IMTs are generally benign or 
A ALK gene and gene fusions

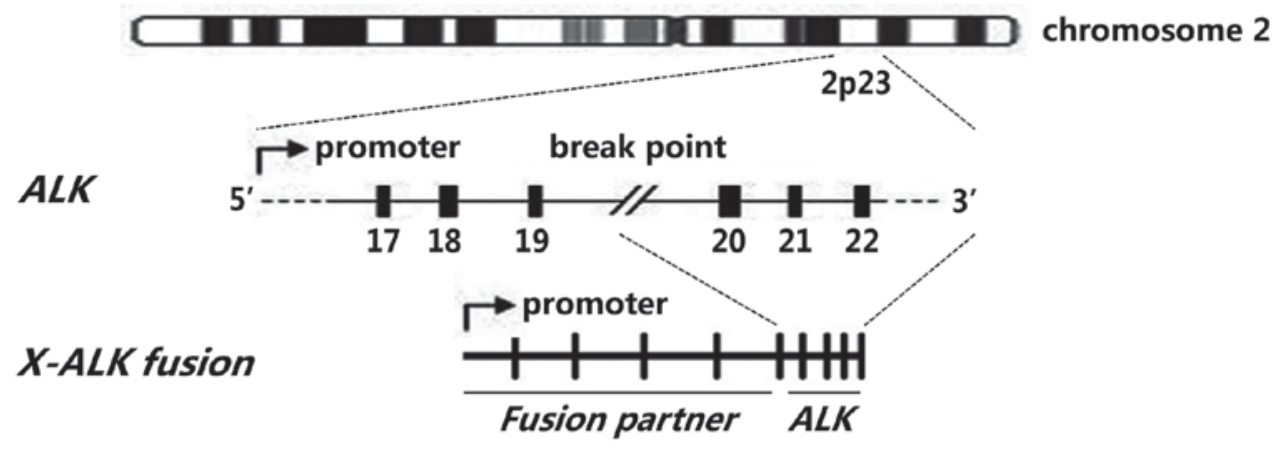

\section{B ALK protein}

\begin{tabular}{l|l|l|l|l|l|}
\hline SP & \multicolumn{3}{c}{ Extracellular domians } & \multicolumn{3}{c|}{ Intracellular domians } \\
\hline
\end{tabular}

Figure 1. Schematic structure of the (A) ALK gene, (B) ALK protein and (C) an ALK oncoprotein, illustrating a prototypical oncogenic rearrangement (5). SP, signal peptide; TM, transmembrane domain; CC, coiled coil domain; ALK, anaplastic lymphoma kinase.

low-grade malignant tumors, and patients usually only require surgical treatment $(49,50)$. According to certain statistics, $\sim 50 \%$ of IMTs are ALK-fusion-positive, and two of the most common fusion partners are TPM3 and TPM4 (51). Similar to ALCL, various $A L K$ fusion partners have been identified in IMTs, including PPF1BP1, PCTN1, RANBP2, EML4, CLTC, $C A R S, A T I C, S E C 31 A$ and $F N 1$ (Table I). Additionally, a study suggested that patients with ALK-fusion-positive IMT may exhibit a more favorable prognosis compared with those with ALK-fusion-negative IMT (52).

Spitz tumors. Spitz tumors are a type of melanocytic neoplasm that tend to occur in younger people (2-35 years old). Spitz tumors may be divided into three subtypes: i) Benign Spitz nevus; ii) atypical Spitz tumor; and iii) Spitz malignant melanoma (53). In 2014, DCTN1-ALK and TPM3-ALK were identified in Spitz tumors $(53,54)$. Follow-up studies have demonstrated that activation of the X-ALK oncoprotein serves an important role in the pathogenesis of Spitz tumors (55).

Renal carcinoma. Renal carcinoma, a type of tumor that originates from cells in the kidney, accounts for $<2 \%$ of all cancer types. Renal carcinoma may be divided into two main subtypes: i) renal cell carcinoma (RCC) with a poor prognosis; and ii) transitional cell carcinoma (accounting for 5-10\% of cases) (56). Due to the difficulty of early diagnosis in renal carcinomas, their pathogenesis is not completely known. $A L K$ fusions have been documented in a small percentage of RCCs $(<1 \%)(57,58)$. Based on clinical settings, RCCs with $A L K$ translocation are divided into two categories: i) RCCs with $V C L-A L K$, composed of sickle cells; and ii) other fusions, which are not associated with sickle cell composition $(59,60)$. In addition to $A L K$ rearrangements, up to $10 \%$ of RCC cases show a low level of $A L K$ copy number gains (58). The therapeutic relevance of these findings in RCC is yet to be established.

Thyroid cancer. Thyroid cancer is a common type of endocrine tumor that is classified as either benign thyroid adenoma or a thyroid malignancy (61). Based on the cells that comprise these tumors, thyroid malignancies can be further divided into four subtypes: i) papillary (PTC; 80-85\%); ii) follicular (10-15\%); iii) medullary (3\%); and iv) anaplastic thyroid cancer (ATC; $2 \%$ ). Among these four types of tumor, the degree of malignance of ATC is high, and its prognosis is poor, with a median patient survival of only 5 months (62-64). In 2015, translocations involving $A L K$ were detected by Chou et al (65), in $2.2 \%$ of PTC patients. Several other $A L K$ fusion genes have been reported in thyroid cancer, including EML4-ALK, TFG-ALK and $S T R N-A L K$ (Table I).

Digestive tract cancer. Digestive tract cancer refers to neoplasms of the digestive system, including cancer of the mouth, esophagus, stomach and intestines. Epidemiological studies have indicated that the frequency of different digestive tract cancer types differs widely in different countries. A recent study illustrated that several factors determine the prognosis of patients with digestive tract cancer, including the location of the tumor, clinical stage and the type of cancer cell (66). In 2006, the TPM4-ALK fusion was first reported in esophageal squamous cell carcinomas (67). Subsequently, other fusion partners have been described in digestive tract cancer, including EML4, CAD and SPTBN1 (68-70).

Other neoplasms. Surveys in which a variety of techniques have been applied to a large series of tumors have revealed differentially convincing evidence of $A L K$ rearrangement in 
Table I. ALK fusion proteins described in diverse tumors.

\begin{tabular}{|c|c|c|c|c|c|}
\hline Gene fusion & Chromosomal aberration & Partner protein & Tumor type & Frequency, \% & (Refs.) \\
\hline$N P M-A L K$ & $\mathrm{t}(2 ; 5)(\mathrm{p} 23 ; \mathrm{q} 35)$ & Nucleophosmin & Lymphoma & 45 & $(3,22)$ \\
\hline$M S N-A L K$ & $\mathrm{t}(\mathrm{X} ; 2)(\mathrm{q} 11-12 ; \mathrm{p} 23)$ & Moesin & Lymphoma & $<1$ & $(106)$ \\
\hline$M Y H 9-A L K$ & $\mathrm{t}(2 ; 22)(\mathrm{p} 23 ; \mathrm{q} 11)$ & $\begin{array}{l}\text { Non-muscle myosin } \\
\text { heavy chain } 9\end{array}$ & Lymphoma & $<1$ & (107) \\
\hline$R N F 213-A L K$ & $\mathrm{t}(2 ; 17)(\mathrm{p} 23 ; \mathrm{q} 25)$ & Ring finger protein 213 & Lymphoma & $<1$ & $(108)$ \\
\hline TRAF1-ALK & $\mathrm{t}(2 ; 9)(\mathrm{p} 23 ; \mathrm{q} 33.2)$ & $\begin{array}{l}\text { Tumor necrosis factor } \\
\text { receptor-associated } \\
\text { factor } 1\end{array}$ & Lymphoma & N/A & $(109)$ \\
\hline$A T I C-A L K$ & $\operatorname{inv}(2)(\mathrm{p} 23 \mathrm{q} 35)$ & $\begin{array}{l}\text { 5-aminoimidazole-4- } \\
\text { carboxamideRibonucleotide } \\
\text { formyltransferase }\end{array}$ & $\begin{array}{l}\text { Lymphoma } \\
\text { IMT }\end{array}$ & $\begin{array}{l}2 \\
<1\end{array}$ & $\begin{array}{l}(110) \\
(39)\end{array}$ \\
\hline$C L T C-A L K$ & $\mathrm{t}(2 ; 17)(\mathrm{p} 23 ; \mathrm{q} 23)$ & Clathrin heavy chain & $\begin{array}{l}\text { Lymphoma } \\
\text { IMT }\end{array}$ & $\begin{array}{l}<1 \\
13\end{array}$ & $\begin{array}{l}(23,108) \\
(111)\end{array}$ \\
\hline SQSTM1-ALK & $\mathrm{t}(2 ; 5)(\mathrm{p} 23.1 ; \mathrm{q} 35.3)$ & Sequestosome 1 & $\begin{array}{l}\text { Lymphoma } \\
\text { Lung cancer }\end{array}$ & $\begin{array}{l}<1 \\
<1\end{array}$ & $\begin{array}{l}(26) \\
(112)\end{array}$ \\
\hline$T F G-A L K$ & $\mathrm{t}(2 ; 3)(\mathrm{p} 23 ; \mathrm{q} 21)$ & $\begin{array}{l}\text { Tyrosine kinase } \\
\text { receptor-fused gene }\end{array}$ & $\begin{array}{l}\text { Lymphoma } \\
\text { Lung cancer } \\
\text { Thyroid cancer }\end{array}$ & $\begin{array}{c}<1 \\
<1 \\
2\end{array}$ & $\begin{array}{l}(113) \\
(39) \\
(63)\end{array}$ \\
\hline TPM4-ALK & $\mathrm{t}(2 ; 19)(\mathrm{p} 23 ; \mathrm{p} 13)$ & Tropomyosin 4 & $\begin{array}{l}\text { Lymphoma } \\
\text { IMT } \\
\text { Digestive tract cancer }\end{array}$ & $\begin{array}{c}3 \\
17 \\
2\end{array}$ & $\begin{array}{l}(114,115) \\
(67)\end{array}$ \\
\hline$T P M 3-A L K$ & $\mathrm{t}(1 ; 2)(\mathrm{q} 21 ; \mathrm{p} 23)$ & Tropomyosin 3 & $\begin{array}{l}\text { Lymphoma } \\
\text { IMT } \\
\text { Renal carcinoma } \\
\text { Spitz tumor }\end{array}$ & $\begin{array}{c}9 \\
21 \\
<1 \\
6\end{array}$ & $\begin{array}{c}(115,116) \\
(39) \\
(53,54)\end{array}$ \\
\hline$A 2 M-A L K$ & $\mathrm{t}(2 ; 12)(\mathrm{p} 23 ; \mathrm{p} 13)$ & $\alpha$-2-macroglobulin & Lung cancer & $<1$ & $(117)$ \\
\hline$H I P 1-A L K$ & $\mathrm{t}(2 ; 7)(\mathrm{p} 23 ; \mathrm{q} 11.23)$ & $\begin{array}{l}\text { Huntingtin-interacting } \\
\text { protein } 1\end{array}$ & Lung cancer & N/A & $(118,119)$ \\
\hline$K I F 5 B-A L K$ & $\mathrm{t}(2 ; 10)(\mathrm{p} 23 ; \mathrm{p} 11)$ & $\begin{array}{l}\text { Kinesin family } \\
\text { member } 5 \mathrm{~B}\end{array}$ & Lung cancer & $<1$ & $(40)$ \\
\hline$K L C 1-A L K$ & $\mathrm{t}(2 ; 14)(\mathrm{p} 23 ; \mathrm{q} 32.1)$ & Kinesin light chain 1 & Lung cancer & N/A & $(41)$ \\
\hline$T P R-A L K$ & $\mathrm{t}(1 ; 2)(\mathrm{q} 31.1 ; \mathrm{p} 23)$ & $\begin{array}{l}\text { Translocated promoter } \\
\text { region }\end{array}$ & Lung cancer & N/A & $(120)$ \\
\hline$E M L 4-A L K$ & $\operatorname{inv}(2)(\mathrm{p} 21 \mathrm{p} 23)$ & $\begin{array}{l}\text { Echinoderm microtubule- } \\
\text { associated protein like- } 4\end{array}$ & $\begin{array}{l}\text { Lung cancer } \\
\text { IMT } \\
\text { Thyroid cancer } \\
\text { Renal carcinoma } \\
\text { Digestive tract cancer } \\
\text { Breast cancer }\end{array}$ & $\begin{array}{c}5 \\
<1 \\
2 \\
<1 \\
\text { N/A } \\
<1\end{array}$ & $\begin{array}{l}(4) \\
(50) \\
(121) \\
(39) \\
(71) \\
(71)\end{array}$ \\
\hline$D C T N 1-A L K$ & $\operatorname{inv}(2)(\mathrm{p} 13 \mathrm{p} 23)$ & Dynactin & $\begin{array}{l}\text { Lung cancer } \\
\text { IMT } \\
\text { Thyroid cancer } \\
\text { Spitz tumor }\end{array}$ & $\begin{array}{c}<1 \\
<1 \\
<1 \\
4\end{array}$ & $\begin{array}{c}(112,122) \\
(123) \\
(53,54)\end{array}$ \\
\hline$C A R S-A L K$ & $\mathrm{t}(2 ; 11 ; 2)(\mathrm{p} 23 ; \mathrm{p} 15 ; \mathrm{q} 31)$ & Cysteinyl-tRNA synthetase & IMT & $<1$ & $(108)$ \\
\hline PPFIBP1-ALK & $\mathrm{t}(2 ; 12)(\mathrm{p} 23 ; \mathrm{p} 11)$ & $\begin{array}{l}\text { Protein tyrosine } \\
\text { phosphatase, receptor type } \\
\text { F-interacting protein, } \\
\text { binding protein } 1\end{array}$ & IMT & $<1$ & $(124)$ \\
\hline SEC 31A-ALK & $\mathrm{t}(2 ; 4)(\mathrm{p} 23 ; \mathrm{q} 21)$ & SEC31 homolog A & IMT & $<1$ & $(125)$ \\
\hline FN1-ALK & $\operatorname{inv}(2)(\mathrm{p} 23 \mathrm{q} 34)$ & Fibronectin 1 & $\begin{array}{l}\text { IMT } \\
\text { Ovarian sarcoma }\end{array}$ & $\begin{array}{l}<1 \\
<1\end{array}$ & $\begin{array}{c}(126) \\
(73)\end{array}$ \\
\hline$R A N B P 2-A L K$ & $\operatorname{inv}(2)(p 23 q 11-13)$ & RAN binding protein 2 & $\begin{array}{l}\text { IMT } \\
\text { Leukemia }\end{array}$ & $\begin{array}{c}3 \\
<1\end{array}$ & $\begin{array}{c}(127) \\
(72)\end{array}$ \\
\hline
\end{tabular}


Table I. Continued.

\begin{tabular}{|c|c|c|c|c|c|}
\hline Gene fusion & Chromosomal aberration & Partner protein & Tumor type & Frequency, \% & (Refs.) \\
\hline$S T R N-A L K$ & $\mathrm{t}(2)(\mathrm{p} 23 ; \mathrm{p} 22.2)$ & Striatin & $\begin{array}{l}\text { Thyroid cancer } \\
\text { Renal carcinoma }\end{array}$ & $\begin{array}{l}<1 \\
\text { N/A }\end{array}$ & $(63,128)$ \\
\hline$V C L-A L K$ & $\mathrm{t}(2 ; 10)(\mathrm{p} 23 ; \mathrm{q} 22)$ & Vinculin & Renal carcinoma & $<1$ & (59) \\
\hline$C A D-A L K$ & $\operatorname{inv}(2)(\mathrm{p} 23 ; \mathrm{p} 22)$ & $\begin{array}{l}\text { Carbamoyl-phosphate } \\
\text { synthetase } 2 \text {, aspartate } \\
\text { transcarbamylase, } \\
\text { and dihydroorotase }\end{array}$ & Digestive tract cancer & $<1$ & (69) \\
\hline SPTBN1-ALK & $\mathrm{t}(2)(\mathrm{p} 16.2 ; \mathrm{p} 23)$ & Spectrin $\beta$ non-erythrocytic 1 & Digestive tract cancer & $<1$ & (70) \\
\hline
\end{tabular}

Not all $A L K$ fusions identified worldwide are included; clear statistics are not available for several ALK fusions found in tumors. IMT, inflammatory myofibroblastic tumor; N/A, data unavailable.

rare cases of breast carcinoma (fusions in 5 out of 209 cases assessed by RT-PCR) (71), leukemia (fusions in 3 out of 1,708 cases assessed by RT-PCR) (72) and ovarian carcinoma (3 out of 69 tumors expressed ALK) (73). Although these reports are technically sound, for the most part, the relevance of these findings remains to be clarified through functional studies in pertinent models.

\section{Therapeutic implications}

ALK is a compelling therapeutic target, as it is a critical oncogenic driver in diverse tumor types of different lineages. However, its expression and functions are limited in normal tissues. Indeed, Bilsland et al (74) confirmed that $A L K$ double-knockout mice exhibited no significant phenotypic differences, a normal life span, no structurally detectable defects and minor behavioral abnormalities, which advocates a wide non-toxic therapeutic window of ALK-specific inhibition. Various therapeutic methods for tumor treatment are currently in development, including direct targeting of activated ALK with small-molecule inhibitors or immunotherapeutic agents and modulation of downstream signaling intermediates in cancer types with $A L K$ rearrangement. In addition, the X-ALK fusion oncoprotein predominantly activates the RAS/MAPK cell proliferation pathway, in addition to the PI3K/AKT/mTOR and JAK/STAT cell survival pathways. Therefore, an understanding of these downstream effectors has prompted the development of novel therapeutic strategies, some of which are being tested in preclinical/clinical trials.

Multiple structurally distinct ALK drugs are being developed based on a deep understanding of the structure of ALK (Table II), three of which are currently in clinical use for the treatment of $A L K$-fusion-positive lung cancer, including crizotinib, ceritinib and alectinib. Crizotinib, an oral ALK TKI, has been extensively studied in preclinical and clinical settings. Early phase I studies (PROFILE 1001) have indicted notable activity of crizotinib, with satisfactory tolerability in patients with $A L K$-fusion-positive NSCLC $(75,76)$. Two-phase III studies further demonstrated the superiority of crizotinib to standard chemotherapy in patients with advanced NSCLC with $X$-ALK. One of these studies (PROFILE 1007) illustrated that crizotinib treatment significantly prolonged progression-free survival (PFS), which was the primary end point, compared with chemotherapy with either pemetrexed or docetaxel (7.7 vs. 3.0 months, respectively) (77). Another study (PROFILE 1014) compared crizotinib with carboplatin or cisplatin plus pemetrexed in 343 patients with advanced $X$ - $A L K$ NSCLC, and clarified the significance of crizotinib as a first-line treatment for these tumors (78). Furthermore, crizotinib displayed excellent activity in IMT and ALCL cases harboring $X-A L K$ fusions (79).

Despite the excellent efficacy of crizotinib in the setting of NSCLC with $A L K$ translocation, almost all patients developed resistance to crizotinib, but the exact molecular mechanism underlying this phenomenon is yet to be confirmed. The known mechanisms that confer intrinsic or acquired resistance to crizotinib are as follows: i) secondary mutations in the $A L K$ kinase domain $(\mathrm{L} 1152 \mathrm{R}$, C1156Y, I1171T, F1174C/L/V, L1196M, G1202R, S1206Y, E1210K and G1269A/S); ii) $A L K$ gene amplification; and iii) activation of alternative ALK-independent survival pathways, including the EGF signaling pathway, the IGF signaling pathway, the RAS/SRC signaling pathway, and the AKT/mammalian target of rapamycin (mTOR) signaling pathway (80-87). Synergistic and/or complementary treatment strategies to overcome resistance are being investigated. Second-generation ALK TKIs, such as ceritinib and alectinib, have been demonstrated to be effective not only in crizotinib-sensitive patients, but also in those who are resistant to crizotinib. Furthermore, other therapeutic options to overcome drug resistance have been proposed, e.g., the use of heat shock protein 90 (HSP90) inhibitors, which can indirectly inhibit ALK fusion $(88,89)$.

Currently, multiple ALK TKIs, including ceritinib, alectinib, lorlatinib, entrectinib, brigatinib, CEP-28122, TSR-011, X-396 and ASP3026, are being investigated as potential therapies for cancer types characterized by $A L K$ rearrangement (Table II). Ceritinib, a highly potent and selective TKI, was approved by the Food and Drug Administration (FDA) as a second-line treatment for patients with $X-A L K$ NSCLC, and following unsuccessful treatment with crizotinib. A total of 114 patients with $A L K$-fusion-positive NSCLC were enrolled in a global multi-institutional phase I trial, among whom $70 \%$ 
Table II. Novel drugs for use in therapies targeting $A L K$ rearrangement tumors.

\begin{tabular}{|c|c|c|c|c|}
\hline Drug & Molecular target & Tumor & Phase & (Refs.) \\
\hline Crizotinib & $\begin{array}{l}N P M-A L K, \\
E M L A-A L K, \\
R A N B P 2-A L K\end{array}$ & $\begin{array}{l}\text { Lung cancer } \\
\text { IMT }\end{array}$ & $\begin{array}{l}\text { Approved by FDA } \\
\text { Phase II/III ongoing }\end{array}$ & $\begin{array}{c}(75-78) \\
(129,130)\end{array}$ \\
\hline Ceritinib & EML4-ALK & $\begin{array}{l}\text { Lung cancer } \\
\text { Thyroid cancer }\end{array}$ & $\begin{array}{l}\text { Approved by FDA } \\
\text { Phase II/III ongoing }\end{array}$ & $\begin{array}{l}(90) \\
(79)\end{array}$ \\
\hline Alectinib & $E M L 4-A L K$ & Lung cancer & Approved by FDA & $(131,132)$ \\
\hline Lorlatinib & $N P M-A L K, E M L 4-A L K$ & $\begin{array}{l}\text { Lung cancer } \\
\text { Lymphoma }\end{array}$ & $\begin{array}{l}\text { Phase I/II ongoing } \\
\text { Phase I/II ongoing }\end{array}$ & $\begin{array}{c}(133,134) \\
(135)\end{array}$ \\
\hline Entrectinib & $\begin{array}{l}E M L 4-A L K \\
C A D-A L K\end{array}$ & $\begin{array}{l}\text { Lung cancer } \\
\text { Digestive tract cancer }\end{array}$ & $\begin{array}{l}\text { Phase I/II ongoing } \\
\text { Phase I/II ongoing }\end{array}$ & $\begin{array}{l}(98) \\
(69)\end{array}$ \\
\hline Brigatinib & NPM-ALK, EML4-ALK & Lung cancer & Phase I/II ongoing & $(136,137)$ \\
\hline CEP-28122 & $N P M-A L K$ & $\begin{array}{l}\text { Lung cancer } \\
\text { Lymphoma }\end{array}$ & $\begin{array}{l}\text { Preclinical study } \\
\text { Preclinical study }\end{array}$ & (138) \\
\hline TSR-011 & EML4-ALK & Lung cancer & Phase I/II ongoing & (139) \\
\hline$X-396$ & $E M L 4-A L K$ & Lung cancer & Phase I/II ongoing & $(98)$ \\
\hline ASP3026 & NPM-ALK, EML4-ALK & $\begin{array}{l}\text { Lung cancer } \\
\text { Lymphoma }\end{array}$ & $\begin{array}{l}\text { Phase I ended } \\
\text { Phase I ended }\end{array}$ & $\begin{array}{c}(134,140) \\
(96)\end{array}$ \\
\hline $\begin{array}{l}\text { Retaspimycin } \\
\text { (HSP90 inhibitor) }\end{array}$ & EML4-ALK & Lung cancer & Preclinical study & $(88,89)$ \\
\hline $\begin{array}{l}\text { Tanespimycin } \\
\text { (HSP90 inhibitor) }\end{array}$ & $\begin{array}{l}N P M-A L K, E M L 4-A L K, \\
T P R-A L K, R A N B P 2-A L K\end{array}$ & $\begin{array}{l}\text { Lung cancer } \\
\text { Lymphoma } \\
\text { IMT }\end{array}$ & $\begin{array}{l}\text { Preclinical study } \\
\text { Preclinical study } \\
\text { Preclinical study }\end{array}$ & $\begin{array}{c}(141) \\
(100) \\
(84)\end{array}$ \\
\hline
\end{tabular}

Only clinically available drugs are listed; the development of ASP3026 was discontinued due to strategic adjustment of the company. IMT, inflammatory myofibroblastic tumor; HSP90, heat shock protein 90; ALK, anaplastic lymphoma kinase; FDA, Food and Drug Administration.

were crizotinib-sensitive and $30 \%$ were crizotinib-resistant. All patients received at least $400 \mathrm{mg}$ of crizotinib per day, and the overall response rate (ORR) was 59\% (90). Alectinib is a TKI used clinically that exhibits minimal inhibitory activity against kinases other than ALK and RET $(91,92)$. Furthermore, in vitro and in vivo studies have demonstrated that alectinib effectively inhibits ALK with or without the gatekeeper mutation L1196M (92). A separate clinical study was conducted to investigate the safety and activity of alectinib in TKI-naive patients with $X-A L K$ NSCLC, with an ORR of $48 \%$ (93). Lorlatinib, which is structurally similar to crizotinib, has been demonstrated to be active against identified crizotinib-resistant ALK mutations, such as the most common mutation seen clinically (G1202R) (94). In 2014, Brigatinib received breakthrough therapy designation from the FDA and a nationwide phase III clinical study in which brigatinib was compared with crizotinib in patients with $X$-ALK NSCLC was recently initiated (95). Furthermore, the antitumor activities of at least 5 other novel ALK inhibitors, including entrectinib, CEP-28122, TSR-011, X-396 and ASP3026, have been shown in vitro, and these agents are currently under clinical investigation (96-98). In addition to targeting ALK directly, several pharmacological strategies allow its indirect targeting. Specifically, HSP90 inhibitors, including retaspimycin and tanespimycin, have displayed certain clinical efficacy in the treatment of patients with ALK rearrangements $(84,99,100)$.

\section{Conclusion}

ALK fusions are remarkably versatile oncoproteins that may drive a variety of tumors of different lineages, including, but not limited to, lymphoma, lung cancer, IMTs, Spitz tumors, renal carcinoma, thyroid cancer, digestive tract cancer, breast cancer, leukemia and ovarian carcinoma. Furthermore, a profusion of $A L K$ fusion partners has been consistently identified in $A L K$-translocated cancer types, which are unique neoplasms that can be effectively targeted by several clinically available TKIs, including crizotinib, ceritinib and alectinib. By using alternative methods of tumor detection, novel $A L K$ translocations may be discovered in upcoming years, which may reveal novel aspects of ALK biology. Substantial efforts are focused on therapeutic considerations and novel approaches to target ALK, including rationally designed tyrosine kinase inhibitors, the study of resistance mechanisms, the design of dual-blockade therapeutic strategies that target downstream signaling intermediates, and immunotherapy against activated receptor tyrosine kinases.

In addition to disease-causing gene mutations, genome-level alterations, including chromosomal imbalances and instability, clonal chromosomal aberrations (CCAs, also known as recurrent karyotypic alterations) and non-clonal chromosome aberrations (NCCAs), also serve a significant role in carcinogenesis and the development of malignant tumors. Since cancer-specific aneuploidy 
catalyzes karyotypic variation, the degree of aneuploidy predicts the clinical risk of tumor progression. Increasing evidence has indicated the complexity of cancer, which cannot be explained by somatic mutation theory. To address this complexity, additional ad hoc explanations have been postulated, and carcinogenesis is thought to represent a problem of tissue organization on the basis of tissue organization field theory (101-103). According to recent studies, chromosomal aberration-mediated genome evolution is responsible for all major transitions in cancer evolution, including phenotypic plasticity, metastasis and drug resistance $(104,105)$. It is believed that the genome serves as the evolutionary platform that links gene/epigene interaction and multiple levels of omics, which can be driven by genome-level alteration rather than individual hallmarks as gene mutation or epigenetic alteration. Conclusively, ongoing research with the aim of characterizing the clinicopathological and biological consequences of $A L K$ rearrangement may allow us to better understand the genome-mediated evolutionary mechanism of cancer.

\section{Acknowledgements}

Not applicable.

\section{Funding}

The present review was supported by the National Natural Science Foundation of China (grant no. 81728012), the Natural Science Foundation of Zhejiang Province (grant no. LY18H160065), the Zhejiang Medical and Health Science and Technology Plan Project (grant no. 2018260845), the Science Foundation of Zhejiang Sci-Tech University (grant no. 14042107-Y), the National Undergraduate Training Program for Innovation and Entrepreneurship and Graduate Research and Innovation Projects of Zhejiang Sci-Tech University, China.

\section{Availability of data and materials}

Not applicable.

\section{Authors' contributions}

ZFC and WBO drafted the manuscript. ZFC, QG, MXF, NN and YTP were responsible for the collection of the relevant literature. WBO designed the outline and revised the manuscript. All authors have read and approved the final manuscript.

\section{Ethics approval and consent to participate}

Not applicable.

\section{Patient consent for publication}

Not applicable.

\section{Competing interests}

The authors declare that they have no competing interests.

\section{References}

1. Yao S, Cheng M, Zhang Q, Wasik M, Kelsh R and Winkler C: Anaplastic lymphoma kinase is required for neurogenesis in the developing central nervous system of zebrafish. PLoS One 8: e63757, 2013.

2. Morris SW, Kirstein MN, Valentine MB, Dittmer KG, Shapiro DN, Saltman DL and Look AT: Fusion of a kinase gene, ALK, to a nucleolar protein gene, NPM, in non-Hodgkin's lymphoma. Science 263: 1281-1284, 1994.

3. Morris SW, Kirstein MN, Valentine MB, Dittmer K, Shapiro DN, Look AT and Saltman DL: Fusion of a kinase gene, ALK, to a nucleolar protein gene, NPM, in non-Hodgkin's lymphoma. Science 267: 316-317, 1995 .

4. Soda M, Choi YL, Enomoto M, Takada S, Yamashita Y, Ishikawa S, Fujiwara S, Watanabe H, Kurashina K, Hatanaka H, et al: Identification of the transforming EML4-ALK fusion gene in non-small-cell lung cancer. Nature 448: 561-566, 2007.

5. Mariño-Enríquez A and Dal Cin P: ALK as a paradigm of oncogenic promiscuity: Different mechanisms of activation and different fusion partners drive tumors of different lineages. Cancer Genet 206: 357-373, 2013.

6. Ninomiya H, Kato M, Sanada M, Takeuchi K, Inamura K, Motoi N, Nagano H, Nomura K, Sakao Y, Okumura S, et al: Allelotypes of lung adenocarcinomas featuring ALK fusion demonstrate fewer onco- and suppressor gene changes. BMC Cancer 13: 8, 2013.

7. Bunting SF and Nussenzweig A: End-joining, translocations and cancer. Nat Rev Cancer 13: 443-454, 2013.

8. Shaw AT and Engelman JA: ALK in lung cancer: Past, present, and future. J Clin Oncol 31: 1105-1111, 2013.

9. Cui S, Zhang W, Xiong L, Pan F, Niu Y, Chu T, Wang H, Zhao Y and Jiang L: Use of capture-based next-generation sequencing to detect ALK fusion in plasma cell-free DNA of patients with non-small-cell lung cancer. Oncotarget 8: 2771-2780, 2017.

10. Pekar-Zlotin M,Hirsch FR, Soussan-Gutman L, Ilouze M, Dvir A, Boyle T, Wynes M, Miller VA, Lipson D, Palmer GA, et al: Fluorescence in situ hybridization, immunohistochemistry, and next-generation sequencing for detection of EML4-ALK rearrangement in lung cancer. Oncologist 20: 316-322, 2015.

11. Hofman P, Ilie M, Hofman V, Roux S, Valent A, Bernheim A, Alifano M, Leroy-Ladurie F, Vaylet F, Rouquette I, et al: Immunohistochemistry to identify EGFR mutations or ALK rearrangements in patients with lung adenocarcinoma. Ann Oncol 23: 1738-1743, 2012.

12. Li T, Maus MK, Desai SJ, Beckett LA, Stephens C, Huang E, Hsiang J, Zeger G, Danenberg KD, Astrow SH and Gandara DR: Large-scale screening and molecular characterization of EML4-ALK fusion variants in archival non-small-cell lung cancer tumor specimens using quantitative reverse transcription polymerase chain reaction assays. J Thorac Oncol 9: 18-25, 2014.

13. Jaffe ES, Harris NL, Stein H and Vardiman JW: Pathology and genetics of tumours of haematopoietic and lymphoid tissues. IARC Press, 2001

14. Cheson BD, Fisher RI, Barrington SF, Cavalli F, Schwartz LH, Zucca E, Lister TA; Alliance, Australasian Leukaemia and Lymphoma Group; Eastern Cooperative Oncology Group; European Mantle Cell Lymphoma Consortium, et al: Recommendations for initial evaluation, staging, and response assessment of Hodgkin and non-Hodgkin lymphoma: The Lugano classification. J Clin Oncol 32: 3059-3068, 2014.

15. Medeiros LJ and Elenitobajohnson KS: Anaplastic large cell lymphoma. Am J Clin Pathol 127: 707-722, 2007.

16. Gustafson S, Medeiros LJ, Kalhor $\mathrm{N}$ and Buesoramos CE: Anaplastic large cell lymphoma: Another entity in the differential diagnosis of small round blue cell tumors. Ann Diagn Pathol 13: 413-427, 2009.

17. Damm-Welk C, Pillon M, Woessmann W and Mussolin L: Prognostic factors in paediatric anaplastic large cell lymphoma: Role of ALK. Front Biosci (Schol Ed) 7: 205-216, 2015.

18. Holla VR, Elamin YY, Bailey AM, Johnson AM, Litzenburger BC, Khotskaya YB, Sanchez NS, Zeng J, Shufean MA, Shaw KR, et al: ALK: A tyrosine kinase target for cancer therapy. Cold Spring Harb Mol Case Stud 3: a001115, 2017.

19. Savage KJ, Harris NL, Vose JM, Ullrich F, Jaffe ES, Connors JM, Rimsza L, Pileri SA, Chhanabhai M, Gascoyne RD, et al: ALK-anaplastic large-cell lymphoma is clinically and immunophenotypically different from both ALK+ ALCL and peripheral T-cell lymphoma, not otherwise specified: Report from the International peripheral T-cell lymphoma project. Blood 111: 5496-5504, 2008. 
20. Roskoski R Jr: Anaplastic lymphoma kinase (ALK): Structure, oncogenic activation, and pharmacological inhibition. Pharmacol Res 68: 68-94, 2013.

21. Delsol G, Lamant L, Mariamé B, Pulford K, Dastugue N, Brousset P, Rigal-Huguet F, al Saati T, Cerretti DP, Morris SW and Mason DY: A new subtype of large B-cell lymphoma expressing the ALK kinase and lacking the 2; 5 translocation. Blood 89: 1483-1490, 1997.

22. Laurent C, Do C, Gascoyne RD, Lamant L, Ysebaert L, Laurent G, Delsol G and Brousset P: Anaplastic lymphoma kinase-positive diffuse large B-cell lymphoma: A rare clinicopathologic entity with poor prognosis. J Clin Oncol 27: 4211-4216, 2009.

23. Gascoyne RD, Lamant L, Martin-Subero JI, Lestou VS, Harris NL, Müller-Hermelink HK, Seymour JF, Campbell LJ, Horsman DE, Auvigne I, et al: ALK-positive diffuse large B-cell lymphoma is associated with Clathrin-ALK rearrangements: Report of 6 cases. Blood 102: 2568-2573, 2003

24. Van Roosbroeck K, Cools J, Dierickx D, Thomas J, Vandenberghe P, Stul M, Delabie J, De Wolf-Peeters C, Marynen P and Wlodarska I: ALK-positive large B-cell lymphomas with cryptic SEC31A-ALK and NPM1-ALK fusions. Haematologica 95: 509-513, 2010.

25. Bedwell C, Rowe D, Moulton D, Jones G, Bown N and Bacon CM: Cytogenetically complex SEC31A-ALK fusions are recurrent in ALK-positive large B-cell lymphomas. Haematologica 96: 343-346, 2011

26. Takeuchi K, Soda M, Togashi Y, Ota Y, Sekiguchi Y, Hatano S, Asaka R, Noguchi M and Mano H: Identification of a novel fusion, SQSTM1-ALK, in ALK-positive large B-cell lymphoma. Haematologica 96: 464-467, 2011.

27. D'Amore ES, Visco C, Menin A, Famengo B, Bonvini $\mathrm{P}$ and Lazzari E: STAT3 pathway is activated in ALK-positive large B-cell lymphoma carrying SQSTM1-ALK rearrangement and provides a possible therapeutic target. Am J Surg Pathol 37: 780-786, 2013

28. Torre LA, Bray F, Siegel RL, Ferlay J, Lortet-Tieulent J and Jemal A: Global cancer statistics, 2012. CA Cancer J Clin 65: 87-108, 2015.

29. Ettinger DS, Akerley W, Borghaei H, Chang AC, Cheney RT, Chirieac LR, D'Ámico TA, Demmy TL, Ganti AK, Govindan R, et al: Non-small cell lung cancer. J Natl Compr Canc Netw 10: 1236-1271, 2012.

30. Koivunen JP, Mermel C, Zejnullahu K, Murphy C, Lifshits E, Holmes AJ, Choi HG, Kim J, Chiang D, Thomas R, et al: EML4-ALK fusion gene and efficacy of an ALK kinase inhibitor in lung cancer. Clin Cancer Res 14: 4275-4283, 2008.

31. Rodig SJ, Mino-Kenudson M, Dacic S, Yeap BY, Shaw A, Barletta JA, Stubbs H, Law K, Lindeman N, Mark E, et al: Unique clinicopathologic features characterize ALK-rearranged lung adenocarcinoma in the western population. Clin Cancer Res 15: 5216-5223, 2009.

32. Shaw AT, Yeap BY, Mino-Kenudson M, Digumarthy SR, Costa DB, Heist RS, Solomon B, Stubbs H, Admane S, McDermott U, et al: Clinical features and outcome of patients with non-small-cell lung cancer who harbor EML4-ALK. J Clin Oncol 27: 4247-4253, 2009.

33. Li Y, Li Y, Yang T, Wei S, Wang J, Wang M, Wang Y, Zhou Q, Liu $\mathrm{H}$ and Chen J: Clinical significance of EML4-ALK fusion gene and association with EGFR and KRAS gene mutations in 208 Chinese patients with non-small cell lung cancer. PLoS One 8: e52093, 2013.

34. Shaozhang Z, Xiaomei L, Aiping Z, Jianbo H, Xiangqun S and Qitao Y: Detection of EML4-ALK fusion genes in non-small cell lung cancer patients with clinical features associated with EGFR mutations. Genes Chromosomes Cancer 51: 925-932, 2012.

35. Zhang X, Zhang S, Yang X, Yang J, Zhou Q, Yin L, An S, Lin J, Chen S, Xie Z, et al: Fusion of EML4 and ALK is associated with development of lung adenocarcinomas lacking EGFR and KRAS mutations and is correlated with ALK expression. Mol Cancer 9: 188, 2010.

36. Wong DW, Leung EL, So KK, Tam IY, Sihoe AD, Cheng LC, Ho KK, Au JS, Chung LP and Pik Wong M; University of Hong Kong Lung Cancer Study Group: The EML4-ALK fusion gene is involved in various histologic types of lung cancers from nonsmokers with wild-type EGFR and KRAS. Cancer 115: $1723-1733,2009$

37. Guo Y, Ma J, Lyu X, Liu H, Wei B, Zhao J, Fu S, Ding L and Zhang J: Non-small cell lung cancer with EML4-ALK translocation in Chinese male never-smokers is characterized with early-onset. BMC Cancer 14: 834, 2014.
38. Ou SH, Bartlett CH, Mino-Kenudson M, Cui J and Iafrate AJ: Crizotinib for the treatment of ALK-rearranged non-small cell lung cancer: A success story to usher in the second decade of molecular targeted therapy in oncology. Oncologist 17: $1351-1375,2012$

39. Rikova K, Guo A, Zeng Q, Possemato A, Yu J, Haack H, Nardone J, Lee K, Reeves C, Li Y, et al: Global survey of phosphotyrosine signaling identifies oncogenic kinases in lung cancer. Cell 131: 1190-1203, 2007.

40. Takeuchi K, Choi YL, Togashi Y, Soda M, Hatano S, Inamura K, Takada S, Ueno T, Yamashita Y, Satoh Y, et al: KIF5B-ALK, a novel fusion oncokinase identified by an immunohistochemistry-based diagnostic system for ALK-positive lung cancer. Clin Cancer Res 15: 3143-3149, 2009.

41. Togashi Y, Soda M, Sakata S, Sugawara E, Hatano S, Asaka R, Nakajima T, Mano $\mathrm{H}$ and Takeuchi K: KLC1-ALK: A novel fusion in lung cancer identified using a formalin-fixed paraffin-embedded tissue only. PLoS One 7: e31323, 2012.

42. Nishino M, Klepeis VE, Yeap BY, Bergethon K, Morales-Oyarvide V, Dias-Santagata D, Yagi Y, Mark EJ, Iafrate AJ and Mino-Kenudson M: Histologic and cytomorphologic features of ALK-rearranged lung adenocarcinomas. Mod Pathol 25: 1462-1472, 2012

43. Lee JK, Kim TM, Koh Y, Lee SH, Kim DW, Jeon YK, Chung DH, Yang SC, Kim YT, Kim YW, et al: Differential sensitivities to tyrosine kinase inhibitors in NSCLC harboring EGFR mutation and ALK translocation. Lung Cancer 77: 460-463, 2012.

44. Yang J, Zhang X, Su J, Chen H, Tian H, Huang Y, Xu C and Wu YL: Concomitant EGFR mutation and EML4-ALK gene fusion in non-small cell lung cancer. J Clin Oncol 29 (Suppl 15): S10517-S10517, 2011

45. Popat S, Vieira de Araújo A, Min T, Swansbury J, Dainton M, Wotherspoon A, Lim E, Nicholson AG and O'Brien ME: Lung adenocarcinoma with concurrent exon 19 EGFR mutation and ALK rearrangement responding to erlotinib. J Thorac Oncol 6: 1962-1963, 2011.

46. Kris MG, Johnson BE, Kwiatkowski DJ, Iafrate AJ, Wistuba II, Aronson SL, Engelman JA, Shyr Y, Khuri FR, Rudin CM, et al: Identification of driver mutations in tumor specimens from 1,000 patients with lung adenocarcinoma: The NCI's lung cancer mutation consortium (LCMC). J Clin Oncol 29: CRA7506, 2011.

47. Leuschner I: Inflammatory myofibroblastic tumor. Pathologe 31: 106-108, 2010 (In German).

48. Coffin CM, Watterson J,Priest JR and Dehner LP: Extrapulmonary inflammatory myofibroblastic tumor (inflammatory pseudotumor). A clinicopathologic and immunohistochemical study of 84 cases. Am J Surg Pathol 19: 859-872, 1995.

49. Coffin CM, Hornick JL and Fletcher CD: Inflammatory myofibroblastic tumor: Comparison of clinicopathologic, histologic, and immunohistochemical features including ALK expression in atypical and aggressive cases. Am J Surg Pathol 31: 509-520, 2007.

50. Sokai A, Enaka M, Sokai R, Mori S, Mori S, Gunji M, Fujino M and Ito M: Pulmonary inflammatory myofibroblastic tumor harboring EML4-ALK fusion gene. Jpn J Clin Oncol 44: 93-96, 2014.

51. Griffin CA, Hawkins AL, Dvorak C, Henkle C, Ellingham T and Perlman EJ: Recurrent involvement of 2p23 in inflammatory myofibroblastic tumors. Cancer Res 59: 2776-2780, 1999.

52. Chun YS, Wang L, Nascimento AG, Moir CR and Rodeberg DA: Pediatric inflammatory myofibroblastic tumor: Anaplastic lymphoma kinase (ALK) expression and prognosis. Pediatr Blood Cancer 45: 796-801, 2005.

53. Busam KJ, Kutzner H, Cerroni L and Wiesner T: Clinical and pathologic findings of Spitz nevi and atypical Spitz tumors with ALK fusions. Am J Surg Pathol 38: 925-933, 2014.

54. Wiesner T, He J, Yelensky R, Esteve-Puig R, Botton T, Yeh I, Lipson D, Otto G, Brennan K, Murali R, et al: Kinase fusions are frequent in Spitz tumours and spitzoid melanomas. Nat Commun 5: 3116, 2014.

55. Yeh I, de la Fouchardiere A, Pissaloux D, Mully TW, Garrido MC, Vemula SS, Busam KJ, LeBoit PE, McCalmont TH and Bastian BC: Clinical, histopathologic, and genomic features of Spitz tumors with ALK fusions. Am J Surg Pathol 39: 581-591, 2015.

56. Seo AN, Yoon G and Ro JY: Clinicopathologic and molecular pathology of collecting duct carcinoma and related renal cell carcinomas. Adv Anat Pathol 24: 65-77, 2017.

57. Stöhr CG, Amann K and Hartmann A: Histopathologie des Nierenzellkarzinoms. Der Urologe 52: 942-948, 2013. 
58. Sukov WR, Hodge JC, Lohse CM, Akre MK, Leibovich BC, Thompson RH and Cheville JC: ALK alterations in adult renal cell carcinoma: Frequency, clinicopathologic features and outcome in a large series of consecutively treated patients. Mod Pathol 25: 1516-1525, 2012.

59. Mariño-Enríquez A, Ou WB, Weldon CB, Fletcher JA and Pérez-Atayde AR: ALK rearrangement in sickle cell trait-associated renal medullary carcinoma. Genes Chromosomes Cancer 50: 146-153, 2011

60. Debelenko LV, Raimondi SC, Daw N, Shivakumar BR, Huang D, Nelson M and Bridge JA: Renal cell carcinoma with novel VCL-ALK fusion: New representative of ALK-associated tumor spectrum. Mod Pathol 24: 430-442, 2011.

61. Xing M: Molecular pathogenesis and mechanisms of thyroid cancer. Nat Rev Cancer 13: 184-199, 2013.

62. Smallridge RC and Copland JA: Anaplastic thyroid carcinoma: Pathogenesis and emerging therapies. Clin Oncol (R Coll Radiol) 22: 486-497, 2010.

63. Kelly LM, Barila G, Liu P, Evdokimova VN, Trivedi S, Panebianco F, Gandhi M, Carty SE, Hodak SP, Luo J, et al: Identification of the transforming STRN-ALK fusion as a potential therapeutic target in the aggressive forms of thyroid cancer. Proc Natl Acad Sci USA 111: 4233-4238, 2014

64. Baudin E and Schlumberger M: New therapeutic approaches for metastatic thyroid carcinoma. Lancet Oncol 8: 148-156, 2007.

65. Chou A, Fraser S, Toon CW, Clarkson A, Sioson L, Farzin M, Cussigh C, Aniss A, O'Neill C, Watson N, et al: A detailed clinicopathologic study of ALK-translocated papillary thyroid carcinoma. Am J Surg Pathol 39: 652-659, 2015.

66. Rassouli FB, Matin MM and Saeinasab M: Cancer stem cells in human digestive tract malignancies. Tumor Biol 37: 7-21, 2016.

67. Jazii FR, Najafi Z, Malekzadeh R, Conrads TP, Ziaee AA Abnet C, Yazdznbod M, Karkhane AA and Salekdeh GH: Identification of squamous cell carcinoma associated proteins by proteomics and loss of beta tropomyosin expression in esophageal cancer. World J Gastroenterol 14: 7104-7112, 2006.

68. Aisner DL, Nguyen TT, Paskulin DD, Le AT, Haney J, Schulte N, Chionh F, Hardingham J, Mariadason J, Tebbutt N, et al: ROS1 and ALK fusions in colorectal cancer, with evidence of intratumoral heterogeneity for molecular drivers. Mol Cancer Res 12: 111-118, 2014.

69. Amatu A, Somaschini A, Cerea G, Bosotti R, Valtorta E, Buonandi P, Marrapese G, Veronese S, Luo D, Hornby Z, et al: Novel CAD-ALK gene rearrangement is drugable by entrectinib in colorectal cancer. Br J Cancer 113: 1730-1734, 2015.

70. Ying J, Lin C, Wu J, Guo L, Qiu T, Ling Y, Shan L, Zhou H, Zhao D, Wang J, et al: Anaplastic lymphoma kinase rearrangement in digestive tract cancer: Implication for targeted therapy in Chinese population. PLoS One 10: e0144731, 2015.

71. Lin E, Li L, Guan Y, Soriano R, Rivers CS, Mohan S, Pandita A, Tang J and Modrusan Z: Exon array profiling detects EML4-ALK fusion in breast, colorectal, and non-small cell lung cancers. Mol Cancer Res 7: 1466-1476, 2009.

72. Röttgers S, Gombert M, Teigler-Schlegel A, Busch K, Gamerdinger U, Slany R, Harbott J and Borkhardt A: ALK fusion genes in children with atypical myeloproliferative leukemia. Leukemia 24: 1197-1200, 2010.

73. Ren H, Tan ZP, Zhu X, Crosby K, Haack H, Ren JM, Beausoleil S, Moritz A, Innocenti G, Rush J, et al: Identification of anaplastic lymphoma kinase as a potential therapeutic target in ovarian cancer. Cancer Res 72: 3312-3323, 2012.

74. Bilsland JG, Wheeldon A, Mead A, Znamenskiy P, Almond S, Waters KA, Thakur M, Beaumont V, Bonnert TP, Heavens R, et al: Behavioral and neurochemical alterations in mice deficient in anaplastic lymphoma kinase suggest therapeutic potential for psychiatric indications. Neuropsychopharmacology 33: 685-700, 2007.

75. Camidge DR, Bang YJ, Kwak EL, Iafrate AJ, Varella-Garcia M, Fox SB, Riely GJ, Solomon B, Ou SH, Kim DW, et al: Activity and safety of crizotinib in patients with ALK-positive non-small-cell lung cancer: Updated results from a phase 1 study. Lancet Oncol 13: 1011-1019, 2012.

76. Kwak EL, Bang YJ, Camidge DR, Shaw AT, Solomon B, Maki RG, Ou SH, Dezube BJ, Jänne PA, Costa DB, et al: Anaplastic lymphoma kinase inhibition in non-small-cell lung cancer. N Engl J Med 363: 1693-1703, 2010.

77. Shaw AT, Kim DW, Nakagawa K, Seto T, Crinó L, Ahn MJ, De Pas T, Besse B, Solomon BJ, Blackhall F, et al: Crizotinib versus chemotherapy in advanced ALK-positive lung cancer. $\mathrm{N}$ Engl J Med 368: 2385-2394, 2013
78. Solomon BJ, Mok T, Kim DW, Wu YL, Nakagawa K, Mekhail T, Felip E, Cappuzzo F, Paolini J, Usari T, et al: First-line crizotinib versus chemotherapy in ALK-positive lung cancer. N Engl J Med 371: 2167-2177, 2014

79. Godbert Y, Henriques de Figueiredo B, Bonichon F, Chibon F, Hostein I, Pérot G, Dupin C, Daubech A, Belleannée G, Gros A, et al: Remarkable response to crizotinib in woman with anaplastic lymphoma kinase-rearranged anaplastic thyroid carcinoma. J Clin Oncol 33: e84-e87, 2015.

80. Choi YL, Soda M, Yamashita Y, Ueno T, Takashima J, Nakajima T, Yatabe Y, Takeuchi K, Hamada T, Haruta H, et al: EML4-ALK mutations in lung cancer that confer resistance to ALK inhibitors. N Engl J Med 363: 1734-1739, 2010.

81. Heuckmann JM, Hölzel M, Sos ML, Heynck S, Balke-Want H, Koker M, Peifer M, Weiss J, Lovly CM, Grütter C, et al: ALK mutations conferring differential resistance to structurally diverse ALK inhibitors. Clin Cancer Res 17: 7394-7401, 2011.

82. Doebele RC, Pilling AB, Aisner DL, Kutateladze TG, Le AT, Weickhardt AJ, Kondo KL, Linderman DJ, Heasley LE, Franklin WA, et al: Mechanisms of resistance to crizotinib in patients with ALK gene rearranged non-small cell lung cancer. Clin Cancer Res 18: 1472-1482, 2012.

83. Katayama R, Shaw AT, Khan TM, Mino-Kenudson M, Solomon BJ, Halmos B, Jessop NA, Wain JC, Yeo AT, Benes C, et al: Mechanisms of acquired crizotinib resistance in ALK-rearranged lung cancers. Sci Transl Med 4: 120ra117, 2012.

84. Sasaki T, Okuda K, Zheng W, Butrynski J, Capelletti M, Wang L, Gray NS, Wilner K, Christensen JG, Demetri G, et al: The neuroblastoma associated F1174L ALK mutation causes resistance to an ALK kinase inhibitor in ALK translocated cancers. Cancer Res 70: 10038-10043, 2010

85. Crystal AS, Shaw AT, Sequist LV, Friboulet L, Niederst MJ, Lockerman EL, Frias RL, Gainor JF, Amzallag A, Greninger P, et al: Patient-derived models of acquired resistance can identify effective drug combinations for cancer. Science 346: 1480-1486, 2014

86. Ji C, Zhang L, Cheng Y, Patel R, Wu H, Zhang Y, Wang M, Ji S, Belani CP, Yang JM and Ren X: Induction of autophagy contributes to crizotinib resistance in ALK-positive lung cancer. Cancer Biol Ther 15: 570-577, 2014.

87. Mengoli MC, Barbieri F, Bertolini F, Tiseo M and Rossi G: K-RAS mutations indicating primary resistance to crizotinib in ALK-rearranged adenocarcinomas of the lung: Report of two cases and review of the literature. Lung Cancer 93: 55-58, 2016.

88. Sequist LV, Gettinger S, Senzer NN, Martins RG, Jänne PA, Lilenbaum R, Gray JE, Iafrate AJ, Katayama R, Hafeez N, et al: Activity of IPI-504, a novel heat-shock protein 90 inhibitor, in patients with molecularly defined non-small-cell lung cancer. J Clin Oncol 28: 4953-4960, 2010.

89. Normant E, Paez G, West KA, Lim AR, Slocum KL, Tunkey C, McDougall J, Wylie AA, Robison K, Caliri K, et al: The Hsp90 inhibitor IPI-504 rapidly lowers EML4-ALK levels and induces tumor regression in ALK-driven NSCLC models. Oncogene 30: 2581-2586, 2011.

90. Shaw AT, Kim DW, Mehra R, Tan DS, Felip E, Chow LQ, Camidge DR, Vansteenkiste J, Sharma S, De Pas T, et al: Ceritinib in ALK-rearranged non-small-cell lung cancer. N Engl J Med 370: 1189-1197, 2014

91. Kodama T, Tsukaguchi T, Satoh Y, Yoshida M, Watanabe Y, Kondoh $\mathrm{O}$ and Sakamoto $\mathrm{H}$ : Alectinib shows potent antitumor activity against RET-rearranged non-small cell lung cancer. Mol Cancer Ther 13: 2910-2918, 2014.

92. Sakamoto H, Tsukaguchi T, Hiroshima S, Kodama T, Kobayashi T, Fukami TA, Oikawa N, Tsukuda T, Ishii N and Aoki Y: CH5424802, a selective ALK inhibitor capable of blocking the resistant gatekeeper mutant. Cancer Cell 19: 679-690, 2011.

93. Shaw AT, Gandhi L, Gadgeel S, Riely GJ, Cetnar J, West H, Camidge DR, Socinski MA, Chiappori A, Mekhail T, et al: Alectinib in ALK-positive, crizotinib-resistant, non-small-cell lung cancer: A single-group, multicentre, phase 2 trial. Lancet Oncol 17: 234-242, 2016.

94. Zou HY, Friboulet L, Kodack DP, Engstrom LD, Li Q, West M, Tang RW, Wang H, Tsaparikos K, Wang J, et al: PF-06463922, an ALK/ROS1 inhibitor, overcomes resistance to first and second generation ALK inhibitors in preclinical models. Cancer Cell 28: $70-81,2015$. 
95. Huang WS, Liu S, Zou D, Thomas M, Wang Y, Zhou T, Romero J, Kohlmann A, Li F, Qi J, et al: Discovery of Brigatinib (AP26113), a phosphine oxide-containing, potent, orally active inhibitor of anaplastic lymphoma kinase. J Med Chem 59: 4948-4964, 2016.

96. George SK, Vishwamitra D, Manshouri R, Shi P and Amin HM: The ALK inhibitor ASP3026 eradicates NPM-ALK+ T-cell anaplastic large-cell lymphoma in vitro and in a systemic xenograft lymphoma model. Oncotarget 5: 5750-5763, 2014

97. Lee J, Kim HC, Hong JY, Wang K, Kim SY, Jang J, Kim ST, Park JO, Lim HY, Kang WK, et al: Detection of novel and potentially actionable anaplastic lymphoma kinase (ALK) rearrangement in colorectal adenocarcinoma by immunohistochemistry screening. Oncotarget 6: 24320-24332, 2015.

98. Lovly CM, Heuckmann JM, de Stanchina E, Chen H, Thomas RK, Liang C and Pao W: Insights into ALK-driven cancers revealed through development of novel ALK tyrosine kinase inhibitors. Cancer Res 71: 4920-4931, 2011.

99. Sang J, Acquaviva J, Friedland JC, Smith DL, Sequeira M, Zhang C, Jiang Q, Xue L, Lovly CM, Jimenez JP, et al: Targeted inhibition of the molecular chaperone Hsp90 overcomes ALK inhibitor resistance in non-small cell lung cancer. Cancer Discov 3: 430-443, 2013

100. Bonvini P, Gastaldi T, Falini B and Rosolen A: Nucleophosminanaplastic lymphoma kinase (NPM-ALK), a novel Hsp90-clien tyrosine kinase: Down-regulation of NPM-ALK expression and tyrosine phosphorylation in $\mathrm{ALK}(+) \mathrm{CD} 30(+)$ lymphoma cells by the Hsp90 antagonist 17-allylamino, 17-demethoxygeldanamycin. Cancer Res 62: 1559-1566, 2002.

101. Bloomfield $M$ and Duesberg P: Inherent variability of cancer-specific aneuploidy generates metastases. Mol Cytogenet 9: 90, 2016.

102. Heng HH, Regan SM, Liu G and Ye CJ: Why it is crucial to analyze non clonal chromosome aberrations or NCCAs? Mol Cytogenet 9: 15, 2016.

103. Ye CJ, Regan S, Liu G, Alemara S and Heng HH: Understanding aneuploidy in cancer through the lens of system inheritance fuzzy inheritance and emergence of new genome systems. Mol Cytogenet 11: 31, 2018

104. Bloomfield M and Duesberg P: Is cancer progression caused by gradual or simultaneous acquisitions of new chromosomes? Mol Cytogenet 11: 4, 2018.

105. Horne SD, Pollick SA and Heng HH: Evolutionary mechanism unifies the hallmarks of cancer. Int J Cancer 136: 2012-2021, 2015.

106. Tort F, Pinyol M, Pulford K, Roncador G, Hernandez L, Nayach I, Kluin-Nelemans HC, Kluin P, Touriol C, Delsol G, et al: Molecular characterization of a new ALK translocation involving moesin (MSN-ALK) in anaplastic large cell lymphoma. Lab Invest 81: 419-426, 2001.

107. Lamant L, Gascoyne RD, Duplantier MM, Armstrong F, Raghab A, Chhanabhai M, Rajcan-Separovic E, Raghab J, Delsol $G$ and Espinos E: Non-muscle myosin heavy chain (MYH9): A new partner fused to ALK in anaplastic large cell lymphoma. Genes Chromosomes Cancer 37: 427-432, 2003.

108. Cools J, Wlodarska I, Somers R, Mentens N, Pedeutour F, Maes B, De Wolf-Peeters C, Pauwels P, Hagemeijer A and Marynen P: Identification of novel fusion partners of ALK, the anaplastic lymphoma kinase, in anaplastic large-cell lymphoma and inflammatory myofibroblastic tumor. Genes Chromosomes Cancer 34: 354-362, 2002

109. Feldman AL, Vasmatzis G, Asmann YW, Davila J, Middha S, Eckloff BW, Johnson SH, Porcher JC, Ansell SM and Caride A: Novel TRAF1-ALK fusion identified by deep RNA sequencing of anaplastic large cell lymphoma. Genes Chromosomes Cancer 52: 1097-1102, 2013

110. Trinei M, Lanfrancone L, Campo E, Pulford K, Mason DY, Pelicci PG and Falini B: A new variant anaplastic lymphoma kinase (ALK)-fusion protein (ATIC-ALK) in a case of ALK-positive anaplastic large cell lymphoma. Cancer Res 60: 793-798, 2000.

111. Bridge JA, Kanamori M, Ma Z, Pickering D, Hill DA Lydiatt W, Lui MY, Colleoni GW, Antonescu CR, Ladanyi M and Morris SW: Fusion of the ALK gene to the clathrin heavy chain gene, CLTC, in inflammatory myofibroblastic tumor. Am J Pathol 159: 411-415, 2001.

112. Iyevleva AG, Raskin GA, Tiurin VI, Sokolenko AP, Mitiushkina NV, Aleksakhina SN, Garifullina AR, Strelkova TN, Merkulov VO, Ivantsov AO, et al: Novel ALK fusion partners in lung cancer. Cancer Lett 362: 116-121, 2015.
113. Hernández L, Pinyol M, Hernández S, Beà S, Pulford K, Rosenwald A, Lamant L, Falini B, Ott G, Mason DY, et al: TRK-fused gene (TFG) is a new partner of ALK in anaplastic large cell lymphoma producing two structurally different TFG-ALK translocations. Blood 94: 3265-3268, 1999.

114. Liang X, Meech SJ, Odom LF, Bitter MA, Ryder JW, Hunger SP, Lovell MA, Meltesen L, Wei Q, Williams SA, et al: Assessment of $\mathrm{t}(2 ; 5)(\mathrm{p} 23 ; \mathrm{q} 35)$ translocation and variants in pediatric ALK+ anaplastic large cell lymphoma. Am J Clin Pathol 121: 496-506, 2004.

115. Lawrence B, Perez-Atayde A, Hibbard MK, Rubin BP, Dal Cin P, Pinkus JL, Pinkus GS, Xiao S, Yi ES, Fletcher CD and Fletcher JA: TPM3-ALK and TPM4-ALK oncogenes in inflammatory myofibroblastic tumors. Am J Pathol 157: 377-384, 2000.

116. Lamant L, Dastugue N, Pulford K, Delsol G and Mariamé B: A new fusion gene TPM3-ALK in anaplastic large cell lymphoma created by a $(1 ; 2)(q 25 ; p 23)$ translocation. Blood 93: 3088-3095, 1999.

117. Onoda T, Kanno M, Sato H, Takahashi N, Izumino H, Ohta H, Emura T, Katoh H, Ohizumi H, Ohtake H, et al: Identification of novel ALK rearrangement A2M-ALK in a neonate with fetal lung interstitial tumor. Genes Chromosomes Cancer 53: 865-874, 2014

118. Ou SH, Klempner SJ, Greenbowe JR, Azada M, Schrock AB Ali SM, Ross JS, Stephens PJ and Miller VA: Identification of a novel HIP1-ALK fusion variant in non-small-cell lung cancer (NSCLC) and discovery of ALK I1171 (I1171N/S) mutations in two ALK-rearranged NSCLC patients with resistance to Alectinib. J Thorac Oncol 9: 1821-1825, 2014

119. Fang DD, Zhang B, Gu Q, Lira M, Xu Q, Sun H, Qian M, Sheng W, Ozeck M, Wang Z, et al: HIP1-ALK, a novel ALK fusion variant that responds to crizotinib. J Thorac Oncol 9: 285-294, 2014

120. Choi YL, Lira ME, Hong M, Kim RN, Choi SJ, Song JY, Pandy K, Mann DL, Stahl JA, Peckham HE, et al: A novel fusion of TPR and ALK in lung adenocarcinoma. J Thorac Oncol 9: 563-566, 2014.

121. Ji JH, Oh YL, Hong M, Yun JW, Lee HW, Kim D, Ji Y, Kim DH, Park WY, Shin HT, et al: Identification of driving ALK fusion genes and genomic landscape of medullary thyroid cancer. PLoS Genet 11: e1005467, 2015.

122. Wang X, Krishnan C, Nguyen E, Meyer KJ, Oliveira JL, Yang P, Yi ES, Yaszemski MJ, Maran A, Erickson-Johnson MR and Oliveira AM: Fusion of dynactin 1 (DCTN1) to ALK in inflammatory myofibroblastic tumor. Lab Invest, 2011.

123. Shimada Y, Kohno T, Ueno H, Ino Y, Hayashi H, Nakaoku T, Sakamoto Y, Kondo S, Morizane C, Shimada K, et al: An oncogenic ALK fusion and an RRAS mutation in KRAS mutation-negative pancreatic ductal adenocarcinoma. Oncologist 22: $158-164,2017$

124. Takeuchi K, Soda M, Togashi Y, Sugawara E, Hatano S, Asaka R, Okumura S, Nakagawa K, Mano H and Ishikawa Y: Pulmonary inflammatory myofibroblastic tumor expressing a novel fusion, PPFIBP1-ALK: Reappraisal of Anti-ALK immunohistochemistry as a tool for novel ALK fusion identification. Clin Cancer Res 17: 3341-3348, 2011.

125. Panagopoulos I, Nilsson T, Domanski HA, Isaksson M, Lindblom P, Mertens F and Mandahl N: Fusion of the SEC31L1 and ALK genes in an inflammatory myofibroblastic tumor. Int J Cancer 118: 1181-1186, 2006.

126. Ouchi K, Miyachi M, Tsuma Y, Tsuchiya K, Iehara T, Konishi E, Yanagisawa A and Hosoi H: FN1: A novel fusion partner of ALK in an inflammatory myofibroblastic tumor. Pediatric Blood Cancer 62: 909-911,2015.

127. Ma Z, Hill DA, Collins MH, Morris SW, Sumegi J, Zhou M, Zuppan C and Bridge JA: Fusion of ALK to the Ran-binding protein 2 (RANBP2) gene in inflammatory myofibroblastic tumor. Genes Chromosomes Cancer 37: 98-105, 2003.

128. Kusano H, Togashi Y, Akiba J, Moriya F, Baba K, Matsuzaki N, Yuba Y, Shiraishi Y, Kanamaru H, Kuroda N, et al: Two cases of renal cell carcinoma harboring a novel STRN-ALK fusion gene. Am J Surg Pathol 40: 761-769, 2016.

129. Lovly CM, Mcdonald NT, Chen H, Ortiz-Cuaran S, Heukamp LC, Yan Y, Florin A, Ozretić L, Lim D, Wang L, et al: Rationale for co-targeting IGF-1R and ALK inALKfusion positive lung cancer. Nat Med 20: 1027-1034, 2014.

130. Di Paolo D, Yang D, Pastorino F, Emionite L, Cilli M, Daga A, Destafanis E, Di Fiore A, Piaggio F, Brignole C, et al: New therapeutic strategies in neuroblastoma: Combined targeting of a novel tyrosine kinase inhibitor and liposomal siRNAs against ALK. Oncotarget 6: 28774-28789, 2015. 
131. Seto T, Kiura K, Nishio M, Nakagawa K, Maemondo M, Inoue A, Hida T, Yamamoto $\mathrm{N}$, Yoshioka $\mathrm{H}$, Harada $\mathrm{M}$, et al: CH5424802 (RO5424802) for patients with ALK-rearranged advanced non-small-cell lung cancer (AF-001JP study): A single-arm, open-label, phase 1-2 study. Lancet Oncol 14: 590-598, 2013.

132. Gadgeel SM, Gandhi L, Riely GJ, Chiappori AA, West HL, Azada MC, Morcos PN, Lee RM, Garcia L, Yu L, et al: Safety and activity of alectinib against systemic disease and brain metastases in patients with crizotinib-resistant ALK-rearranged non-small-cell lung cancer (AF-002JG): Results from the dose-finding portion of a phase 1/2 study. Lancet Oncol 15: 1119-1128, 2014.

133. Johnson TW, Richardson PF, Bailey S, Brooun A, Burke BJ, Collins MR, Cui JJ, Deal JG, Deng YL, Dinh D, et al: Discovery of (10R)-7-amino-12-fluoro-2,10,16-trimethyl-15-oxo-10,15,16,1 7-tetrahydro-2H-8,4-(metheno)pyrazolo[4,3-h][2,5,11]-benzoxadiazacyclotetradecine-3-carbonitrile (PF-06463922), a macrocyclic inhibitor of anaplastic lymphoma kinase (ALK) and c-ros oncogene 1 (ROS1) with preclinical brain exposure and broad-spectrum potency against ALK-resistant mutations. J Med Chem 57: 4720-4744, 2014.

134. Mologni L, Ceccon M, Pirola A, Chiriano G, Piazza R, Scapozza L and Gambacorti-Passerini C: NPM/ALK mutants resistant to ASP3026 display variable sensitivity to alternative ALK inhibitors but succumb to the novel compound PF-06463922. Oncotarget 6: 5720-5734, 2015.

135. Basit S, Ashraf Z, Lee K and Latif M: First macrocyclic 3rd-generation ALK inhibitor for treatment of ALK/ROS1 cancer: Clinical and designing strategy update of lorlatinib. Eur J Med Chem 134: 348-356, 2017.
136. Katayama R, Khan TM, Benes C, Lifshits E, Ebi H, Rivera VM, Shakespeare WC, Iafrate AJ, Engelman JA and Shaw AT: Therapeutic strategies to overcome crizotinib resistance in non-small cell lung cancers harboring the fusion oncogene EML4-ALK. Proc Natl Acad Sci USA 108: 7535-7540, 2011.

137. Ceccon M, Mologni L, Bisson W, Scapozza L and Gambacorti-Passerini C: Crizotinib-resistant NPM-ALK mutants confer differential sensitivity to unrelated Alk inhibitors. Mol Cancer Res 11: 122-132, 2013.

138. Cheng M, Quail MR, Gingrich DE, Ott GR, Lu L, Wan W, Albom MS, Angeles TS, Aimone LD, Cristofani F, et al: CEP-28122, a highly potent and selective orally active inhibitor of anaplastic lymphoma kinase with antitumor activity in experimental models of human cancers. Mol Cancer Ther 11: 670-679, 2012

139. Arkenau HT, Sachdev JC, Mita MM, Dziadziuszko R, Lin CC Yang JC, Infante JR, Anthony SP, Voskoboynik M, Su WC, et al: Phase (Ph) 1/2a study of TSR-011, a potent inhibitor of ALK and TRK, in advanced solid tumors including crizotinib-resistant ALK positive non-small cell lung cancer. J Clin Oncol 33: 8063-8063, 2015.

140. Mori M, Ueno Y, Konagai S, Fushiki H, Shimada I, Kondoh Y, Saito R, Mori K, Shindou N, Soga T, et al: The selective anaplastic lymphoma receptor tyrosine kinase inhibitor ASP3026 induces tumor regression and prolongs survival in non-small cell lung cancer model mice. Mol Cancer Ther 13: 329-340, 2014.

141. Katayama R, Friboulet L, Koike S, Lockerman EL, Khan TM, Gainor JF, Iafrate AJ, Takeuchi K, Taiji M, Okuno Y, et al: Two novel ALK mutations mediate acquired resistance to the next-generation ALK inhibitor alectinib. Clin Cancer Res 20: 5686-5696, 2014. 